\title{
DIMENSIONS OF GREEN OFFICE EVIDENCE FROM REGENCY/CITY GOVERNMENT OFFICES IN CENTRAL JAVA, INDONESIA
}

\author{
Yusepaldo PASHARIBU ${ }^{1}{ }^{1}$, Agus SUGIARTO ${ }^{\circledR 2}{ }^{2}$, Tutuk ARIARSANTI ${ }^{3}$, Petrus WIJAYANTO ${ }^{4}$ \\ Department of Management, Faculty of Economics and Business, \\ Satya Wacana Christian University, Salatiga, Indonesia \\ E-mails: ${ }^{1} y u s e p a l d o . p a s h a r i b u @ u k s w . e d u$ (corresponding author); ${ }^{2}$ agus.sugiarto@uksw.edu; \\ 3tutuk.arsanti@uksw.edu; ${ }^{4}$ petrus.wijayanto@uksw.edu
}

Received 28 March 2019; accepted 05 July 2019

\begin{abstract}
Green office that is implemented within the environmental management system is one of the current concerns of environmentally friendly advocates. It is to do with the phenomenon of high environmental degradation and the low awareness of people about environmental-friendly behavior. Previous studies have indicated that the application of green office, particularly in government agencies, had not been optimally practiced due to low commitment and scant discussions. This study was thus conducted with the aim of exploring and identifying the various applications and dimensions of the green office concept among government institutions in Central Java, Indonesia. To fulfil the research objectives, a triangulation research method was employed, comprising focus group discussions, in-depth interviews and close observations of the offices located in five (5) municipal government agencies. Results indicated that seven green office dimensions were applied by the government institutions, namely: energy conservation, water conservation, building layouts, office technology, human resource management, work systems, and office waste management.
\end{abstract}

Keywords: green office, e-office, eco-office, office governance, green office dimensions, environmentally friendly.

JEL Classification: M0, O3.

\section{Introduction}

The high occurrence of environmental damage occurring in Indonesia indicates the low awareness of the people's concern for the environment, hence their lack of environmentally friendly behavior. This claim was derived from the data extracted from the ranks of the Environmental Performance Index (EPI) performance on high-priority environmental issues reported in Indonesia. The reports had stated that the quality of Indonesia's environment in 2018 was ranked 133 out of 180 countries, with a score of 46.92, just below the two closest neighboring countries of Singapore, and Malaysia which were respetively ranked 49 and 75 (Yale 2018). Apart from this low environmental quality ranking, the Indonesian government also faced other challenges involving the enviroment such as its lack of organisations in practicing and implementing environmentally friendly office concepts. There was also a report (ESDM 2011) citing Indonesia's lack of realization about the importance of being energy conscious, with many buildings including office buildings, government buildings, shopping centers, educational facilities, health facilities and hotels, being energy-wasteful.

To be frank, the practice of environmentally friendly behavior is difficult to be realized by many parties, including those working in government offices especially in developing countries. This observation is supported by research which showed that the practice of environmental friendly behavior within government offices is in existence but not optimal (Amelia 2014). This sluggish adoption of the green office concept suggests that it is not easy to implement.

Copyright (c) 2019 The Authors. Published by VGTU Press.

This is an Open Access article distributed under the terms of the Creative Commons Attribution License (http://creativecommons.org/licenses/by/4.0/), which permits unrestricted use, distribution, and reproduction in any medium, provided the original author and source are credited.. 
Studies (Oyedokun et al. 2015) have also noted that most implementation of the green office concept seemed to be concentrated within principal cities only which implies that rural areas may be even less aware of the implementation. In the context of a developing nation like Indonesia, the green office phenomenon had just been improvised, hence literature on this aspect of research is scant, particularly on its environmental quality (Minstry of Energy and Mineral Resources - (ESDM 2011). The study by Amelia (2014) helped to drive the point a little more because it seemed obvious that the Indonesian community is still a long way in its green office improvement, especially in the district/ city government offices. It is possible that this situation may be related to the low awareness of the green office cocnept among professionals such as architects, consultants, and clients. This lack of implementation may also be attributed to the reluctance of certain parties to become involved in green buildings and its implementation progress (Bin et al. 2011).

The current high phenomenon of environmental damage happening in the country coupled by its low environmental quality index and poor implementation of the green office concept among the regional government offices suggests that it is imperative for a study of this nature to be conducted so as to explore and to identify in what manner the green office concept can be applied and implemented within the dimensions of the local district/city government offices in Indonesia. The outcome derived can then be used as a reference by future green office concept implementations. The research objective and the respective districts chosen for the current study was based on the reason that these institutions are authorized with the right to determine their own policies, implement them, provide the protection and planning, impact the analysis, keep track of the natural resources and also to develop their own environmental instruments. Such an authority and its duties are contained in the provisions of Article 63, paragraph 3 of Law Number 32 Year 2009, with regards to Environmental Protection and Management.

\section{Literature review}

\subsection{Green office concept}

Based on the World Wildlife Fund's goal of realizing environmentally friendly offices, the concept of the Green Office movement was first conceptualised and implemented in the UK. The idea was later adopted by other countries, including Indonesia. Green office can also be defined as cost-effective office that practically reduces both the corporate cost base as well as its carbon footprint (Calder 2009). In other words, the positive role of the green environment will also create sustainable development that might have a significant impact on the country's economic growth, protection for the planet as well as human beings (Lavrinenko et al. 2019). In this regard, the green office concept is understood as an environmentally friendly office construction procedure that follows environmental ethics, and principles which are applicable to both business and non-business organizations, including government institutions.

The green office criteria required for the environmental management systems were formulated by the World Wildlife Fund (WWF) which had insisted that the minimum criteria be included in the Environment program. It should comprise sustainable development, the establishment of an executive coordinator, and individual awareness development (Amelia 2014). The WWF had also added that the principles of environmentally friendly offices must incldue: (1) Improving the use of environmentally friendly materials, (2) Reducing of waste, including loading waste, (3) Reusing of materials that have been used with different processing; (4) Recycling or reusing of materials; (5) Recovering the use of special materials for the disposal of other needs, and (6) Taking what can be interpreted as power savings in energy production systems (Rantao 2012).

\subsection{Dimensions of Green office}

The green office concept is a broad concept compiled of various dimensions. According to the Leadership in Energy and Environmental Design (GBCI 2014), the eco-friendly concept for organizations is based on six aspects: 1) Building Location, 2) Water use, complete with native plants; rainwater recharge, 3) Energy, utilization of solar panels; energy use from renewable sources, 4) Materials and Sources, utilization of recyclable materials, the presence of waste recycling rooms, 5) Indoor Environmental Quality, availability of smoking rooms, use of low emissions, and 6) Innovation, the utilization of environmentally friendly technologies. Extending on this, Coşkun and Akar (2019) stated that there are three main criteria for green office: 1$)$ Consumption of natural resources (i.e. heating-cooling, electricity, water, paper), 2) Activities (i.e. waste management, building maintenance), and 3) Employees' awareness. The last dimension of the employees' awareness by Coşkun and Akar (2019) is different from the six dimensions of the green office proposed by the GBCI (2014), hence it was added as the seventh dimension.

According to the European Green Office Handbook, there are several environmental performance indicators which encompass: Location and structural design efficiency, Energy efficiency, Water efficiency, Material efficiency, and efforts to improve the quality of the office environment, operational and maintenance optimization, as well as reducing waste and toxic (Povodör et al. 2010). Meanwhile, other dimensions of the green office as suggested by Wastebusters (2000) include: Office waste, Procurement or purchase, Office buildings, Transportation, Technology, and other dimensions of the human resources. The basic principle 
of the green office initiative is to promote the continuous improvement of the office work environment in organizations so that stress and other unhealthy symptoms related to work can be reduced. According to the Business Resource Efficiency Guide (Wrap 2014), the benefits of being a green office include: 1) Reduction of costs, (2) Increase of resource efficiency, (3) Reduction of carbon footprints, (4) Improvement of environmental performance, (5) Enhancement of company image, and (6) Increase in employees' environmental friendly awareness. Similar opinions have been expressed in The Green Office Manual - A Guide to Responsible Practice (Wastebusters 2000).

\section{Methods}

This study is qualitative in design. It focuses on examining the government's environmental offices in Central Java. Data were derived from the responses provided by informants who were employees in these organisations. They were made up of the leaders and staff of these environmental offices which were located in five districts/cities in Central Java - Indonesia - Salatiga City (SAL), the Kudus Regency (KUD), the Semarang Regency (SEM), Magelang City (MAG) and Surakarta City (SUR). The data were were collected over a period of approximately seven months, between December 2017 and June 2018. The background information of all the seven areas is illustrated in Table 1.

Table 1. Demographic and geographic profile of the observation unit (source: Statistics 2017)

\begin{tabular}{|c|l|c|c|}
\hline No & Regency / City & $\begin{array}{c}\text { Number of } \\
\text { Population }\end{array}$ & $\begin{array}{c}\text { Geographical } \\
\text { Area }\end{array}$ \\
\hline 1 & Kudus & 851478 & $425.17 \mathrm{~km}^{2}$ \\
\hline 2 & Semarang & 1027489 & $946.86 \mathrm{~km}^{2}$ \\
\hline 3 & Salatiga & 188928 & $52.96 \mathrm{~km}^{2}$ \\
\hline 4 & Surakarta & 516102 & $44.03 \mathrm{~km}^{2}$ \\
\hline 5 & Magelang & 121112 & $18.12 \mathrm{~km}^{2}$ \\
\hline
\end{tabular}

The triangulation method was applied in this study. First, a search for the secondary data that were related to the green office dimension was made. Next, these data were used as the initial reference for the Focus Group Discussion (FGD) so us to understand how the green office many be a barrier among the regional/city government offices. Following this, an in-depth interview in each government office was then conducted with 25 representatives of the government offices. The questions asked were related to their office's Green Office dimensions that had also been used in the FGD. The representatives comprised six staff from SAL, six staff from the KUD, four staff from SEM, five staff from MAG, and four staff from SUR. For the purpose of this study, they would be coded according to the district they come from followed by their respective number, such as, SUR 1 for the first informant from the Surakarta city. Interviews were conducted face to face in their respective offices for around twenty minutes each. These were then recorded and transcribed verbatim. All interviews were conducted in English. To validate the consistency of the information obtained from the FGDs and the interviews, direct observations were also conducted in the regional/city government offices. These observations were specifically focused on the environmental offices which were expected to become a pilot green office that would also apply the required environmental ethics or rules in order to be noted as being environmentally friendly.

\section{Results and discussion}

Based on the results of the observations, interviews and focus group discussions with the informants, several dimensions of the Green Office concept were identified in the respective regional government offices. Figure 1 highlights these dimensions.

As can be noted, the dimensions encompassed: Electrical Energy conservation, Water conservation, Buildingspatial planning, Application of technology, Human

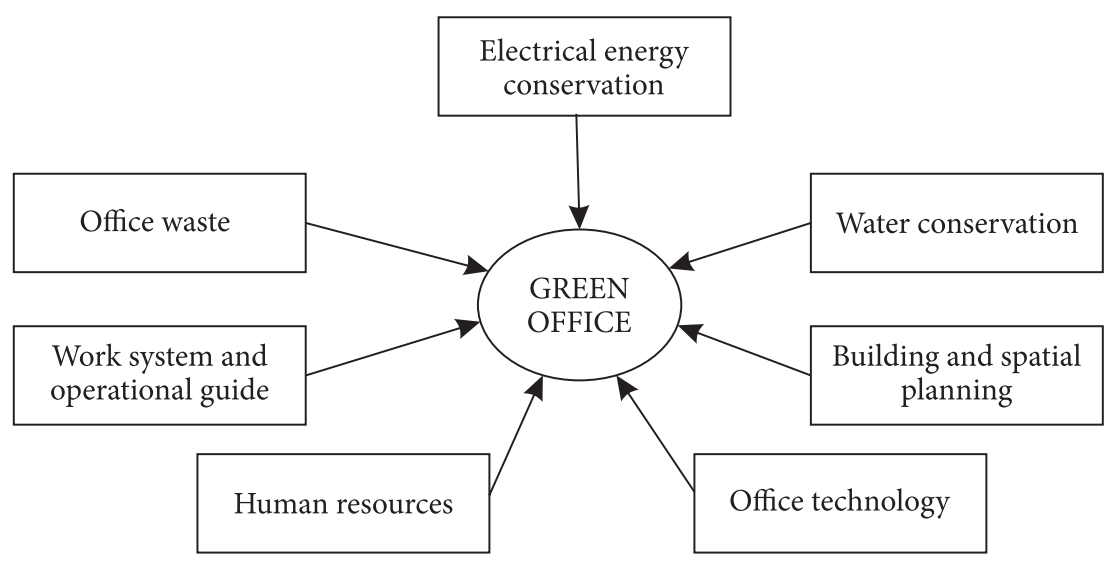

Figure 1. Green office dimensions at the government offices 
resources, Work systems including operational guidance, and Management of office waste. These are further elaborated with evidence traced to the informant's responses.

\subsection{Dimension of electrical energy conservation}

Electrical energy is one of the energies that is needed in supporting the office activities. The problem faced by all the local government offices is the waste of electricity which has an impact on high operational costs (electricity bills) of the offices. This is the main consideration in the implementation of the green office. Termed as energy conservation, this dimension is one of the significant elements for sustainable future. It helps to reduce energy consumption through conservations which can come from the society (Bilgen and Sarıkaya 2018). Support is provided by the informants.

Informant Kud-2, Monitoring of electricity use to be done in every 3 months to check whether it is decrease or not.

This implied that electrical energy conservation in the city offices was based on efficient energy usage, where the use of electricity was being monitored on a quarterly basis so as to check whether it has decreased or not. The monitoring approach is a form of control system that can effectively influence energy consumption reduction so as to realise green office buildings (Ohueri et al. 2018). Interviews drawn from the informants indicated that the Surakarta city had implemented measurements to audit its energy consumption.

Infromant SUR-4: So what we want to recognise is electricity meter' losses, is there any differences between previous and current month.

This statement is in line with the recommendations drawn from the results of most research (Chiaroni et al. 2017) on energy saving, which recommends adjusting the electrical power according to the needs, and also by conducting audits on a regular basis. This is in line with auditing the energy usage via a well-designed energy audit methodology (Li et al. 2018) such as identifying the energy consumption patterns, classifying the energy consumption data, and then measuring the suitability of real-time energy consumption data with record energy consumption patterns.

Another strategy taken to ensure the green office implementation through energy conservation was through energy-efficient lightings such as LED lights and solar lights. This contribution can be traced to the response made by several office informants from several locations.

KS-3: We still use LED lights, then use lights that use solar energy

M-1: There is a special room that uses solar power, there is running text that using solar power, then there are solar powered garden lights
The above informant's statements indicated that the use of technology in the lighting usage such as LED lights seemed to be more common for offices, houses, and industrial sites because they were found to be more efficient when comapred to conventional lights (Magno et al. 2015). The use of the LED lights as one of the lighting tools for energy conservation was also noted by Setiawan and Hartanti (2014) and Idayani et al. (2018). Other efforts made to ensure the efficiency of electrical energy are to use natural lighting where possible, as has been practised by several municipal/district government offices such as designing buildings with ventilation space or large windows so that room lighting is sufficient without using lights. This practice was noted in the following responses.

Informant M-1: we have considered adequate lighting, so we don't use much electricity as well as large ventilation to minimizing the use of air conditioning

Efforts to save energy need to be supported by committed heads of departments in the government bureaus. Their commitment can be strengthened through the the enactment of regulations, the stipulation of rules, and the provision of technical instructions related to energy use (electricity). These technical instructions may include emphasisng on efficient usage of electricity through reminders. In the observations conducted of those offices during this study, it was noticed that there were were clue stickers reminding staff to turn off the lights when not in use. These clue stickers were attached to switches and office walls. In addition, staff also made the effort to regulate the air conditioning unit's temperature. These efforts were carried out by the SUR city government office.

SUR-1: for energy savings, the guidelines are the main guidance in energy saving, such as the instruction either to optimizing air ventilation or to use air conditioning at a certain temperature

Based on the observations and statements of the informants, it cannot be denied that the activities and efforts to control and conduct efficiency in using electrical energy is taken seriously, and it serves as one of the main criteria for realising green office. Energy efficiency as well as green office building are both becoming the parameters for others to determine the property's performance, whether rated as premium or otherwise (Newell et al. 2014). Even energy saving measures such as the use of lightings, air conditioning, and office equipment, both in state-owned and regional government agencies, are currently being regulated by Presidential Instruction No.10 of year 2005 (Yudhoyono 2005). The close observations of the offices during this study also indicated that some government offices were using ecofriendly air conditioning units or they may be using inverter technology which also has an impact on saving energy. In terms of the air conditioning unit with the inverter technology, it was noted that this technology has the potential of 
reducing energy consumption to less than half of those air conditioning units driven by the constant-speed induction motor (Ohyama and Kondo 2008). Through the presentation of these findings, it can be deduced that indicators of energy conservation dimensions in the green office include periodic energy audits, the application of energy-efficient lightings, buildings to deliver natural lightings, and regulations, rules, and instructions for technical equipment such as air conditioners, as a means of fulfilling the energy saving goals.

\subsection{Dimension of water conservation in the office}

The rapid growth in the number of industries and offices has resulted in the increasing need and use of water annually. The results of this study showed that water conservation is also a concern for creating a green office. The staements below further illustrate.

Informant MAG-1: We have started by saving water

Infromant KUD-2: So monitoring the last 3 months of water used is needed to check is there any decreased or not

The efficiency in utilizing water resources is also supported by the Indonesian Presidential Instructions issued. This regulation aims to conserve water usage by changing the inefficient behavior of users on energy and water use (Yudhoyono 2005), including the use of water in the office. The efficiency of water use in the office is one indicator and dimension for practising the environmentally friendly behavior in the office, hereby recognized as a green office (Kubba 2012, Putri et al. 2012). Undeniably, the commitment and exemplary roles from the leadership level can be an important support for the practice of water conservation, as acknowledged below.

Informant SUR-1: Which is the dominant main issue for now regarding energy and water, this used to be a priority which mentioned and supported by the commitment of the mayor. So that, we then do socialization through sharing stickers

Beside water conservation practices, innovations are also needed, for instance, instead of getting direct water from taps, rainfed wells can be built while wastewater management which converts waste water into clean water for reuse can be developed.

Informant SEM-4: Depending on utilization, the rainwater possibly can be used for car wash water, plant flush, and so on. Even some people are brave to drink it

Informant KUD-2: Making a kind of rain-fed well, it can be used to fulfill the water needs there. Thus, in the future, they will develop water waste management, such as re-used or recycle water

Efficient water usage in the office is also one indicator and dimension of the environmentally friendly behavior or the green office concept (Kubba 2012, Putri et al. 2012).
This is in line with the government's aim of reducing water consumption in government buildings and office buildings, as indicated by the Presidential Instruction Number 13, year 2011 for energy and water use. In general, water is used in offices as drinking water, for toilets and bathrooms, cleanliness and pantry use, and the maintenance of plants in offices. The implementation of water conservation based on the presidential instruction needs to be contained in a guide or rule guide so that it is more acceptable and implementable, as propsoed by the informants.

Informant SUR-1: The first thing we need is a guide, right? So, it's a kind of rule guide

Based on the discussion on water conservation, the green office dimension can be summarized as: conducting a regular water use audit, implementing wastewater management, getting regional heads to provide their commitment and support, and extending this need for water conservation throughout the institution by implementing regulations and guidelines for the staff to adhere to.

\subsection{Dimension of building and spatial structure}

Office buildings, especially those of the government offices, can serve as potential spaces to implement energy conservation. Handayani (2010) stated that saving energy (energy efficiency) does not mean reducing all activities related to energy use because dooijg so would have a negative impact on the quality of life, such as cutting down comfort and productivity. Green office buildings can be implemented within government offices because it involves developing buildings with certain structures that are environmentally responsible, and which use resources efficiently, such as through appropriate designs, architecture, operations, maintenance, renovations, and constructions (Uğur and Leblebici 2018). These green buildings should possess building dimensions and spatial structures that comply with the green office dimensions proposed by the GBCI (2014), namely the quality of the indoor environment. The building dimensions required were not only limited to providing special spaces, such as smoking rooms but also architecture of the buildings such as the direction of the buildings that could provide a cool temperature and enough lighting without the support of electrical energy.

Sustainable building materials that are integrated with technological strategy has the potential to strategically reduce the energy consumption of these buildings (Ohueri et al. 2018). Since lighting is one of the important factor enabling human beings to conduct their daily activities, lighting engineering and its planning for buildings play an important role (Setiawan and Hartanti 2014). Energysaving buildings known as green buildings continue to be encouraged as one of the anticipatory steps towards global climate change. The building architecture is referred to as a "green" if it is associated with architectural practices which 
include using renewable resources, passive-active solar photovoltaic (solar cell electricity generation), techniques for using plants for roofing, rainfed gardens, using gravel which is compacted for the pavement area, and others (Sudarwani 2012). Explanations regarding the construction of green buildings need to begin from the design stage, as supported by the responses of the informants.

Informant MAG-1: to pursue the ideal green office, we must start at the planning stage as the foundation of all aspects, which then creates an ideal condition related to environmentally friendly office. For example, in terms of lighting, water use and waste management design

The planning stage, as the foundation for creating an ideal green office should include the use of renewable resources or low emitting materials, the setting of proper ventilation, and location (Gou 2016). The green building interior needs to have three relational layers (urban context, host building and interior fits-outs). In principle, there are general criteria for establishing offices in accordance with the rules of environmental reference including the requirements for the provision of green open space - a longitudinal or clustered area, whose use is more open, where plants grow, whether naturally or intentionally planted (PR Act No. 26 of 2007). The availability of parks and green open spaces in the office area of the district/city government were also noted. Evidence is provided, based on the informants' responses.

Informant SEM-1: This organization planting rare plants with several varieties

Informant SOL-2: Yes we made it like this so that if it works even though our office is an old building, it is not pretentious, but we try to be able to work comfortably with greening so that it automatically becomes beautiful

Informant SOL-2: At a glance, this is our park, even though it is an ancient but comfortable building, it can be seen as a green plant here. Our office also processes compost itself in the backyard even though it is simple for plant care

Informant MAG-1: In our office, there is a garden, ... some corners of the room also have pots with natural plants. There is also a plant behind the office

Informant KUD-1: The criteria, in general, is that all those who are involved in cleaning are all, there are all waste management, there is all green open space including activities for saving energy, saving water as well. What is clear is that every business or activity that will affect the business must have environmental permits

The benefits of green open space in the office, besides for enjoying its beauty, is also to increase air circulation because plants absorb carbon dioxide. Based on those statement, it can be understood that the availability of parks and green open spaces in office areas is one dimension of the green office. Therefore, some respondents' statements also included the planning strategy, use of renewable resources, and energy efficient actions, in line with recommendations of (Ohueri et al. 2018) who stated that the integration of technology, organisational, and occupant behaviour strategy, will critically reduce energy consumption of green office buildings.

Conservation efforts were carried out mainly on buildings so as to produce considerable efficiency in the air system. This approach was applied in order to produce low level energy consumption, and to increase the market of buildings within the scope of energy-efficient buildings (Fitriana 2013). Similar things are related to the scope of energy-efficient buildings, especially electricity because of the impact of good spatial planning.

Informant KS-3: At some points, the lights have been turned off, since this place already bright supported by sunlight

Nonetheless, it cannot be denied that sometimes there are obstacles faced by the district/city government office in implementing green offices, including a legacy office or an old building that might be built without heeding the rules of the green office concept.

Informant MAG-3: The office is mostly occupied from generation to generation, that might have no idea about the concept of how to build an office that affected in an environment-friendly

The office, as a work area, requires a level of comfort that not only includes suitable indoor temperature, adequate incoming solar radiation, clean air quality and airing, but also the quality of the lighting. Indonesia, with sun-rich conditions throughout the year should place natural lighting as a priority in designing its buildings which would have an impact on saving energy consumption (Thojib and Adhitama 2014). Based on the observations, interviews, and the FGD conducted, it seemes clear that the dimensions encompassing green office is also related to the building archicteture and its spatial planning which need to embrace aspects such as good ventilation designs which cater to natural lighting, air circulation, and adequate open spaces including the positioning of potted plants withint the office space so as to encourage clea air circulations.

\subsection{Dimension of office technology}

In general, office technology is one that cannot be totally evaded because it links all the office activities together, for example, to record documents, knowledge, data, knowhows and so on. It is also relevant for the functioning of departments which need to collect, process, reproduce, send, and store information materials efficiently. Due to its abundance usage which supports the office's operations, it is necessary to consider and apply environmentally friendly office technology as a green office concept. One of these environmentally friendly office technologies is the E-office technology which is defined as eco-office. The 
term originated from the words, ecology and office, both of which can be interpreted as an office that implements an environmentally friendly management system because it caters to environmental concerns (Amelia 2014). However, he term, E-office may also be associated with electronics, which is then interpreted as an all office administration service activities system conducted electronically, with the help of communication tools and information systems (Dewandaru 2013). In this study, the intended E-office system is interpreted as a combination of both definitions: the use of technology and information systems for office administration activities accompanied by environmentally friendly management. The green office concept being implemented by government offices currently seems to be by reducing paper usage, or the paperless application, especially for correspondence and reporting activities.

Informant KUD-1: related to online, group communication has been done through WhatsApp application, then some applications also implemented in this office, including for planning using e-planning, related to employee performance called e-performance, and also related to reporting, this will be reported quite online. Finance also has an application

Informant MAG-1: For the meeting information, we have used the WhatsApp group, if there is an invitation, one will be photographed and shared with friends, so it does not need to be reproduced. Then another concrete example, even though this is city policy, but also run at our institution, which is called e-planning, e-budgeting, e-performance

Informant SEM-1: If we are invited, we usually use Whattsup application. Reporting on the environmental activities of the company in the form of semester reports can be online as well

Informant SEM-3: The current intrinsic technology that serves to facilitate performance, obviously also creates conditions for energy savings

The responses of the informants support the government's efforts in implementing the E-office. The paperless communication technique was being implemented as alos noted by previous studies (Fang 2002). This outcome is also in tune with the findings of Anthony Jnr et al. (2018) who noted that there has been an increased interest towards the implementation of Green IT initiatives within governmentbased institutions. Besides the application software used, the green office concept was also supported by lighting such as LED and solar lights, followed by air conditioning inverters. Finally, the use of technology which encouraged the use of smartphone applications such as WhatsApp and various other paperless applications.

\subsection{Dimension of human resource}

The green office program is an educational tool to inspire employees to implement environmentally friendly practices that will ultimately help to reduce the overall costs. One concept that is related to environmentally friendly human resource management is the concept of green human resource (Green HR). It is human resource management that aims to transform employees into environmentally friendly employees. Cherian and Jacob (2012) revealed that the implementation of the concept of Green HR requires an attitude change among staff which focuses on environmental sustainability for Human Resource Management (HRM).

Pandey et al. (2016) argued that Green HRM can serve as a tool for organizations to retain the top talents as these employees become their biggest assets in curtailing wastage and in enhancing operations efficiency. In the Green HRM concept, organizarions need to consider exposing their employees to the proper education of green office, appropriate training and development on the concept of green office, and how this can be implemented within the organizations (Arulrajah et al.2015) so that a green lifestyle can be created and be implemented by everyone. Besides the educational offers, it has also been recommended that adaptations to international experiences, followed by public relations be enhanced so as to avoid future obstacles in the disseminated of the green office model (Adomßent et al. 2019). The behavioral change of staff, from one of destructive behaviour to one of sustainable behaviour needs to be encouraged and nurtured within the environmental value-based approach (Smaliukienè et al. 2019). The responses drawn from the interviews of this study showed that the effort in shaping an environmentally friendly behavior and culture among the employees of the district/city government offices is being implemented.

Informant SOL-3: In the city hall, eco-friendly behavior has been applied, the mayor was indeed a smoker, but at the city hall he announced that that place is a non-smoking area, so he himself becomes a role model with not smoking in that area

Informant SOL-1: The example is important to us, so such leaders want to smoke huddle. If we see a leader like that, we will also follow him, even though where the leader is not here

Informant SEM-2: The behavior of the leader becomes important, gives a tremendous effect as it seems. The habit that was originally forced was but eventually became common place. So, in my opinion, the guidelines go back to the behavior of the leader

Based on the opinions of these informants, it can be seen that the behavior of the leaders has to be foremost ir organizations aim to develop and instil an environmentally friendly culture within their offices. Somehow, the management level has the influential power to encourage staff towards this implementation (Armitage et al. 2011). In addition to the exemplary role of the leaders holding important offices within the organizations, there should 
also be general efforts such as sample behaviors, reminders, exemplary behaviors and so on, all of which point towards being environmentally friendly actions.

Informant SOL-3: We need to have a character that aware about environmentally friendly, how to behave properly about maintaining cleanliness, managing garbage, and how to saving energy

Informant SOL-3: We are doing capacity building through dissemination activities, which aim to establish the importance of the environment for the community

Informant SOL-1: then we do socialization, we share stickers, we share biopori and other tools. We have also carried out socialization related to energy saving and water conservation

As noted above, the informants recommended the practice of being environmentally friendly through proper guidelines, such as poster, pamphlets, and emails (as well as stickers that had been done). They believed that this would raise the staff's awareness on energy efficiency even more (Mokhtar Azizi et al. 2015). Another way to expose staff to this practice of being environmentally friendly is to organise campagins (Cole and Fieselman 2013).

Informant SEM-2: when talking about offices, what is called regulation, reward, and punishment is the key. Forced it is also necessary because it can become a habit, which then becomes an awareness

Based on the above it can thus be concluded that the green office concept that is implemented within the regional government offices has a human resource dimension. Several measurments can be applied, such as, exemplary office leadership, establishing an environmentally friendly character, training, socialization, building an environmentally friendly culture in the office, and awarding or punishing the exemplary behaviors of staff. This dimension of human resources as noted by the current study makes a new contribution towards the green office dimensions of previous studies.

\subsection{Work system and operational guide}

The office systems is generally understood as a whole series of procedures that have become a pattern of roundness and order in the settlement of something in the field of principal functions in office activities. In implementing the environmentally friendly behavior within offices, a technical guide for the employees is necessary. This technical guide should embrace the various steps for implementing green office work adminstration procedures in offices. Further to this, the respective offices would also require proper procedures for running the office operations such as the proper guidance for the procurement of goods including office items, and office supplies. In procurement, the fixed assets, operational goods, consumables, and consumptions also need to be taken into account in order to enforce the concept of being environmentally friendly, and to avoid any practices of damaging the environment and causing energy wastage. Green procurement refers to the steps involved for making any purchases of products. Measurements are introduced to minimize the environmental impact of the products purchased, both on human health and the environmental impact (Ho et al. 2010, Walker and Brammer 2009). In this regard, it is imperative for a policy to be designed for green procurement. This policy may also introduce concepts of buying products that can be recycled, reused and reprocessed, for instance, green packaging, energy efficiency, water efficiency, and non-toxic substances, and others.

Informant KUD-1: There is an instruction from Regent No. 7 of 2017 concerning energy savings in buildings that obviously related to the green office

Informant MAG-2: Commitment from the local government is required, especially from the mayor, deputy mayor, and all ranks of the operational head departments

The above responses provided by the informants are reminiscent of what Olubunmi et al. (2016) stated. They too had observed that the government has a significant and important role to play in leading and promoting the cocnept of the green office development.

Informant SEM-3: essentially there has been a kind of circular letter that appeals for saving water, saving electricity, and adjusting the air conditioner temperature to approximately 24 degrees Celsius

Based on the statements made by the informants from three regions, it can be concluded that the commitments and regulations are very necessary for implementing green office, particularly in the regional government offices. Further, it is also essential for leadership and regulatory commitments to follow so as to establish a teamwork unit for the implementation of the green office development.

Informant SOL-2: We continue to form our own group, so there is a staff who in charge as the head of the electricity saving as well as water, thus this institution also divided the staff into the sub-subgroups activities, so that there are coordinators to monitor all different aspects

Informant SEM-4: A team has been formed in order to save the use of electricity, and also there is a competition related to energy efficiency, and later the staff will install electricity-saving stickers

Clearly, the regional government offices in Central Jave also require operational guidance, as noted by the informants.

Informant MAG-2: There is guidance from the department of the environment ministry, so if they have a meeting, the snacks don't use cardboard, we go back to the past, using a plate and a glass to present it, in order reducing the use of paper 
Informant SEM-3: Well, the person of the department of the environment used to aware in using paper, such as trying to re-use it. For example, if there might be a misprint, so we don't waste it, but it will be reused when needed

A green office implementation supervision system is also needed as an important component in creating green office, as noted by some informants.

Informant SOL-2: In our office, there is a warning sign that stated before we go back to home, we should check everything, such as turn of the lamp or tap water

Informant SOL-1: The task of our team in this group in the operational departments includes electricity savings, so later there will be an electric coordinator that do the final check after office hour

Informant SEM-4: We conducted an energy audit in several institutions, also in other offices even though not every year

Based on the discussion above, it appears that in the green office, there are dimensions of the work system and operational guidelines that need to be provided, such as the availability of green office regulations, the existence of work teams or green office task forces, the existence of standard operating procedures for environmentally friendly behavior for employees, the existence of a supervision system for the implementation of environmentally friendly behavior as well as the availability of supporting equipment and attributes.

\subsection{Management of office waste}

In general, waste is understood as materials discarded from the sources of human activities, and natural processes, and which do not have any economic values. Office waste may be interpreted as wastes originating from office environments such as organic waste, paper, textiles, plastics and metals (Alex 2018) while domestic waste in offices has been identified by Yogaswara (2016) as garbage from canteens, paper and packaging use, and leaf wastes. Doak (2018) described office waste materials as 1) Fibre-based products - office papers, newspapers, cardboards, and 2) Non-fibre products - plastic bags, bottles, glass and others. Based on these descriptions, it seems apparent that waste management has to be detailed into two main activities: waste reduction and waste management. Waste reduction refers to the 3Rs which include reduce (limitation of waste generation), recycle (recycling of garbage), and reuse (waste reuse). In comparison, waste management is related to the effort for developing environmental entrepreneurship through organic output, environmental construction, environmental tourism and recycling (Dudin et al. 2019). Waste management can be divided into five activities: sorting, collecting, transporting, processing and the final processing of waste. Activities to reduce the use of papers can be in the form of an attitude which avoids the use of wasteful papers such as eliminating total use of papers and if print is necessary to do so on recycled papers. As for reuse, papers or carton boxes should be re-used for other purposes. In the term of recycle, materials are expected to be viable as renewable resources. All of these are the important components of waste management (Joshi et al. 2015).

The responses generated from the interviews in this study seemed to show that waste management is one dimension practised by the green office concept among the regional government offices in Central Java. This dimension seemed to be wider than the dimensions of materials and sources noted in previous literature review as submitted by the GBCI (2014).

Informant MAG-2: Our meeting material is usually in soft file format or paperless since we are using flash disk rather than hardcopy

Informant MAG-1: It also happened that there was only a 3-month clean garbage program, but this was completed from January 21 to April 21. In addition, here every Friday there is a garbage bank, everyone must deposit garbage collected at the waste bank

Informant KUD-3: for waste, we have a garbage bank. It has been socialized for the first time about sorted waste and waste that can be processed again, and it has already been implemented, there are already several waste banks that have become our reference, there are 50 garbage banks

Informant SOL-2: We have sorting waste, we cultivate it as much as possible

Informant SEM-4: We do sorting, so we separate these garbage, inorganic, paper, we have special garbage dump if there are laboratory wastes, such as cables

Informant KUD-3: In the waste bank they sort organic and non-organic waste that is also non-organic and can be made into saleable creations

Informant SOL-2: We process organic waste into compost that we use to fertilize plants in the office garden

From the responses indicated above, it can be understood that waste management in the office is widely practised as one dimension of the green office within the district/ city regional government offices. Some efforts noted in this dimension are efforts to minimize the amount of waste, clean garbage activities, create waste banks, sort waste activities, provide sanitation facilities, and to process waste.

\subsection{Integration of Green office dimensions outcome}

Government environmental offices which have implemented the green office dimensions stand to gain several advantages as stated by Wrap (2014), in the preceding subsection of the Dimensions in Green Office. Firstly, while each individual in the government offices is committed in executing 
energy efficiency, water conservation, waste management by following the work system, and the operational guide properly, the gains each stand to benefit from the green office technology is their contribution to cost reduction and resource efficiency. Therefore, each of the employee's efforts, when combined together, as an organization, would significantly contribute towards environmental improvement and performance, thereby, enhancing company image. This outlook is supported by Newell et al. (2014), who stated that organizations that achieve energy ratings and green star schemes gain the added-value of being "top end" premium. From the context of this study, it can be noted that all the seven dimensions of green office had been applied and practised by the district/regional offices of Central Java but it appears that the dimension of human resource carried more weight since human beings play and essential role in enabling all these dimensions to be enforced. This outcome seems to be consistent with the findings of Ahmad (2015), who stated that human resource is the most important asset in resources management. Moreover, through the effective green human resource management, green competencies personnel also play a key role in shaping the organizations' sustainable development (Bombiak 2019).

\section{Conclusions}

This study has detected that seven dimensions of the green office concept had been implemented among the district/ city government offices of Central Java. They encompassed the dimensions of energy conservation, water conservation, buildings and spatial planning, office technology, human resources, work systems, and office operational guidelines, and governance of office waste dimension. It was, however, noted that when compared to previous studies which tended to reveal six dimenions, this study had detected two new dimensions with details in its findings, namely the dimension of human resources and the dimension of work systems and office operational guidelines. In addition, two dimensions, namely building and spatial planning and office waste management, were applied on a wider scope. One dimension, namely building location was found to be not applicable due to the tendency that the office buildings occupied were either inherited or given. Three other dimensions, namely energy conservation, water conservation, and utilization of environmentally friendly office technology were generally applied by the offices under this study.

Based on several analyses conducted, it can be deduced that to implement the green office concept in developing countries like Indonesia, may still be a big challenge. It was observed that even though the green office concept was implemented in the developed countries, a large concentration is still located in the the principal cities. There is still a lack of the green office implementation in districts or suburb areas. Therefore, the green office implementation may still be lacking in areas of the ease of adaptability due to costs. Moreover, the key issues of environmentally friendly behavior and the urgency of awareness to implement green office still require the commitment of government bodies as well as individuals for the implementation to be successful. Thus, individuals from the human resource component has an essential role to play in green office implementation.

\section{Implications}

The implications derived from this study suggest that government offices need to be involved in as many dimensions of green office as possible in order to realize green office implementation. This means that govenrment bodies need to be aware of these dimensions and the strategies it can apply for green office. Expersts need to be developed in areas such as energy and water conservation, auditing of electricity on a regular basis, the introduction of energy saving lightings, recycling activities, socialization, develop guidelines and policies, develop exemplary and committed leaders, pay attention to building dimensions and spatial planning since the planning stage, and implement the necessary technology such as paperless application programs and renewable energy such as LED lights and solar cells. The development of human resources related to green offices needs to be improved followed by the introduction of standardized office systems and operational guidelines. Finally, the implementation of good waster management.

\section{Limitations}

The limitations detected in this study can be further traced. First, the official office of the district/city government offices is far and it was also observed to be less environmentally friendly, in that its adherence to the greeen office dimensions were not in accordance. Hence, the data processing of the results of the interviews and the observations made by the researchers were less optimal. The next limitation is the lack of standardization of the green office implementation among the government environmental offices. There were distinct variations in terms of electrical energy conservation, water conservation, office technology, office waste, work system and operational guide. Another limitation was that the decision for green office implementation could cause potential problems among the other departments of the governemnt offices because the decision came from another department that was not involved with the green office implementation. Thus, problems leading to the analysis of the building and spatial planning dimension may arise. Consequently, each individuals has his/her own level of awareness and perception in coping with green office implementation. This is likley to also vary between departments to departmens and between organizations to organizations. 


\section{Funding}

This work was supported by the Universitas Kristen Satya Wacana, under Grant namely fundamental research program of Vice Rector V in the period 2017-2018.

\section{References}

Adomßent M, Grahl A, Spira F (2019) Putting sustainable campuses into force: Empowering students, staff and academics by the self-efficacy Green Office Model. International Journal of Sustainability in Higher Education 20 (3): 470-481. https://doi.org/10.1108/IJSHE-02-2019-0072

Ahmad S (2015) Green human resource management: Policies and practices. Cogent Business \& Management 2 (1): 1030817. https://doi.org/10.1080/23311975.2015.1030817

Alex S (2018) Sukses Mengolah Sampah Organik Menjadi Pupuk Organik. ISBN 602-99884-4-1. Yogyakarta: Pustaka Baru Press.

Amelia IR (2014) Konsep Eco-Office dalam Rangka Mewujudkan Perkantoran Ramah Lingkungan (Studi pada Kantor Walikota Probolinggo). Jurnal Administrasi Publik 2 (3): 478-484.

Anthony Jnr B, Abdul Majid M, Romli A (2018) Green information technology adoption towards a sustainability policy agenda for government-based institutions: An administrative perspective. Journal of Science and Technology Policy Management 10 (2): 274-300. https://doi.org/10.1108/JSTPM-11-2017-0056

Armitage L, Murugan A, Kato H (2011) Green offices in Australia: a user perception survey. Journal of Corporate Real Estate 13 (3): 169-180. https://doi.org/10.1108/14630011111170454

Arulrajah AA, Opatha H, Nawaratne N (2015) Green human resource management practices: A review. Sri Lankan Journal of Human Resource Management 5 (1): 1-16. https://doi.org/10.4038/sljhrm.v5i1.5624

Bilgen S, Sarıkaya İ (2018) Energy conservation policy and environment for a clean and sustainable energy future. Energy Sources, Part B: Economics, Planning, and Policy 13 (3): 183 189. https://doi.org/10.1080/15567249.2017.1423412

Bin Esa MR, Marhani MA, Yaman R, Noor A, Rashid HA (2011) Obstacles in implementing green building projects in Malaysia. Australian Journal of Basic and Applied Sciences 5 (12): 1806-1812.

Bombiak E (2019) Green human resource management - the latest trend or strategic necessity? Entrepreneurship and Sustainability Issues 6 (4): 1647-1662. https://doi.org/10.9770/jesi.2019.6.4(7)

Calder A (2009) The green office. Association for Computing Machinery.

Cherian J, Jacob J (2012) A study of green HR practices and its effective implementation in the organization: A review. Canadian Center of Science and Education. https://doi.org/10.5539/ijbm.v7n21p25

Chiaroni D, Chiesa V, Franzo S, Frattini F, Latilla VM (2017) Overcoming internal barriers to industrial energy efficiency through energy audit: a case study of a large manufacturing company in the home appliances industry. Clean Technologies and Environmental Policy 19 (4): 1031-1046. https://doi.org/10.1007/s10098-016-1298-5
Cole EJ, Fieselman L (2013) A community-based social marketing campaign at Pacific University Oregon: Recycling, paper reduction, and environmentally preferable purchasing. International Journal of Sustainability in Higher Education 14 (2): 176-195. https://doi.org/10.1108/14676371311312888

Coşkun A, Akar N (2019) WWF-Turkey's Green office initiatives green behavior and corporate social responsibility in Asia (pp. 47-55). Emerald Publishing Limited.

https://doi.org/10.1108/978-1-78756-683-520191006

Dewandaru DS (2013) Pemanfaatan Aplikasi E-Office untuk Mendukung Reformasi Birokrasi Studi Kasus: Pusjatan. Sesindo 2013.

Doak AG (2018) Ejector hood: US Patent App. 15/661,180.

Dudin MN, Ivashchenko NP, Gurinovich AG, Tolmachev OM, Sonina LA (2019) Environmental entrepreneurship: characteristics of organization and development. Entrepreneurship and Sustainability Issues 6 (4): 1861-1871. https://doi.org/10.9770/jesi.2019.6.4(22)

ESDM CT (2011). Pemborosan Energi https://www.esdm.go.id/ en/media-center/news-archives/pemborosan-energi-80-persen-faktor-manusia

Fang Z (2002) E-government in digital era: concept, practice, and development. International Journal of the Computer, the Internet and Management 10 (2): 1-22.

Fitriana AN (2013) Kantor Sewa Di Mega Kuningan dengan Pendekatan Arsitektur Hemar Energi. Universitas Gadjah Mada.

GBCI (2014) Green building Council Indonesia http://www. gbcindonesia.org/2012-08-01-03-25-31/2012-08-02-03-4334/rating-tools

Gou Z (2016) Green building for office interiors: Challenges and opportunities. Facilities 34 (11/12): 614-629.

https://doi.org/10.1108/F-04-2015-0022

Handayani T (2010) Effisiensi energi dalam rancangan bangunan. Jurnal Spektrum Sipil 1 (2): 102-108.

Ho LW, Dickinson NM, Chan GY (2010) Green procurement in the Asian public sector and the Hong Kong private sector. Paper presented at the Natural Resources Forum. https://doi.org/10.1111/j.1477-8947.2010.01274.x

Idayani J, Asmawati E, Marlina M (2018) Analisis Titik Impas (Break Even Point) Penggunaan Lampu LED untuk Penerangan: Studi Kasus Gedung TG Universitas X di Surabaya. Jurnal Bisnis Terapan 1 (02): 83-90. https://doi.org/10.24123/jbt.v1i02.797

Joshi G, Naithani S, Varshney V, Bisht SS, Rana V, Gupta P (2015) Synthesis and characterization of carboxymethyl cellulose from office waste paper: A greener approach towards waste management. Waste Management 38: 33-40. https://doi.org/10.1016/j.wasman.2014.11.015

Kubba S (2012) Handbook of green building design and construction: LEED, BREEAM, and Green Globes: ButterworthHeinemann. https://doi.org/10.1016/B978-0-12-385128-4.00003-2

Lavrinenko O, Ignatjeva S, Ohotina A, Rybalkin O, Lazdans D (2019) The role of Green economy in sustainable development (Case Study: The EU States). Entrepreneurship and Sustainability Issues 6 (3): 1113-1126. https://doi.org/10.9770/jesi.2019.6.3(4) 
Li W, Piao M, Huang B, Qu C (2018) Energy data analysis of Green office building. Advances in Computer and Computational Sciences (pp. 671-679). Springer.

https://doi.org/10.1007/978-981-10-3773-3_65

Magno M, Polonelli T, Benini L, Popovici E (2015) A low cost, highly scalable wireless sensor network solution to achieve smart LED light control for green buildings. IEEE Sensors Journal 15 (5): 2963-2973.

https://doi.org/10.1109/JSEN.2014.2383996

Mokhtar Azizi NS, Wilkinson S, Fassman E (2015) Strategies for improving energy saving behaviour in commercial buildings in Malaysia. Engineering, Construction and Architectural Management 22 (1): 73-90.

https://doi.org/10.1108/ECAM-04-2014-0054

Newell G, MacFarlane J, Walker R (2014) Assessing energy rating premiums in the performance of green office buildings in Australia. Journal of Property Investment \& Finance 32 (4): 352-370. https://doi.org/10.1108/JPIF-10-2013-0061

Ohueri CC, Enegbuma WI, Kenley R (2018) Energy efficiency practices for Malaysian green office building occupants. Built Environment Project and Asset Management 8 (2): 134-146. https://doi.org/10.1108/BEPAM-10-2017-0091

Ohyama K, Kondo T (2008) Energy-saving technologies for inverter air conditioners. IEEJ Transactions on Electrical and Electronic Engineering 3 (2): 183-189. https://doi.org/10.1002/tee.20254

Olubunmi OA, Xia PB, Skitmore M (2016) Green building incentives: A review. Renewable and Sustainable Energy Reviews 59: 1611-1621. https://doi.org/10.1016/j.rser.2016.01.028

Oyedokun T, Jones C, Dunse N (2015) The growth of the green office market in the UK. Journal of European Real Estate Research 8 (3): 267-284.

https://doi.org/10.1108/JERER-05-2015-0025

Pandey S, Viswanathan V, Kamboj P (2016) Sustainable green HRM - importance and factors affecting successful implementation in organizations. International Journal of Research in Management and Business 2 (3): 11-29.

Povodör A, Bodroghelyi C, Mouazan, Erwan (2010) European Green office handbook (K. A. f. S. E. (Hungary) Ed., Vol. 510859-LLP-1-2010-1-HU-LEONARDO-LNW.

Putri AA, Rohman MA, Utomo C (2012) Penilaian Kriteria Green Building pada Gedung Teknik Sipil ITS. Jurnal Teknik ITS 1 (1): D107-D112.

Rantao A (2012, 2 January 2012) System and principles of environmental management. Kompasiana https://www. kompasiana.com/aryrantao/550b8f768133111422b1e151./ sistem-dan-prinsip-menejemen-lingkungan
Setiawan B, Hartanti G (2014) Pencahayaan Buatan pada Pendekatan Teknis dan Estetis untuk Bangunan dan Ruang Dalam. Humaniora 5 (2): 1222-1233. https://doi.org/10.21512/humaniora.v5i2.3265

Smaliukienė R, Smaliukienė R, Monni S (2019) A step-by-step approach to social marketing in energy transition. Insights into Regional Development 1 (1): 19-32. https://doi.org/10.9770/ird.2019.1.1(2)

Statistics (2017) Sosial dan Kependudukan. Statistics of Jawa Tengah Province https://jateng.bps.go.id/

Sudarwani MM (2012) Penerapan Green Architecture dan Green Building sebagai upaya pencapaian sustainable Architecture. Dinamika Sains 10 (24).

Thojib J, Adhitama MS (2014) Kenyamanan Visual Melalui Pencahayaan Alami Pada Kantor (Studi Kasus Gedung Dekanat Fakultas Teknik Universitas Brawijaya Malang). RUAS (Review of Urbanism and Architectural Studies) 11 (2): 10-15. https://doi.org/10.21776/ub.ruas.2013.011.02.2

Uğur LO, Leblebici N (2018) An examination of the LEED green building certification system in terms of construction costs. Renewable and Sustainable Energy Reviews 81: 1476-1483. https://doi.org/10.1016/j.rser.2017.05.210

Walker H, Brammer S (2009) Sustainable procurement in the United Kingdom public sector. Supply Chain Management: An International Journal 14 (2): 128-137. https://doi.org/10.1108/13598540910941993

Wastebusters (2000) The Green office manual: a guide to responsible practice. Earthscan.

Wrap (2014) Green office:a guide to running a more cost-effective and environmentally sustainable office. Banbury, Oxon: The Old Academy.

Yale (2018) 2018 EPI Results. Environmental Performance Index https://epi.envirocenter.yale.edu/epi-topline

Yogaswara G (2016) Pengelolaan Sampah Domestik di Perkantoran. Kompasiana https://www.kompasiana.com/gyogaswara/ 57d115325eafbdbd3a2c260c/pengelolaan-sampah-domestikdi-perkantoran

Yudhoyono SB (2005) Instruksi Presiden Republik Indonesia Nomor 10 Tahun 2005 Tentang Penghematan Energi. Jakarta https://www.google.com/url?sa=t\&rct=j\&q=\&esrc=s\&sourc $\mathrm{e}=$ web \&cd=2\&ved=2ahUKEwj83Ky9wJ_hAhUq5YMKHWG8BykQFjABegQIBhAC\&url=http\%3A\%2F\%2F202.61.104.1$80 \% 2$ Fkepres-inpres-perpres\%2Finstruksi-presiden $\% 2$ F63-inpres-no-10-tahun-2005-ttg-penghematan-energi\%2Fdownloa d\&usg=AOvVaw1m3qAHcuwA2Qy3IBxDGCMY 